\title{
Comparison of sheep and goat preferences for leafy spurge
}

\author{
JOHN W. WALKER, SCOTT L. KRONBERG, SAUD L. AL-ROWAILY AND NEIL E. WEST
}

At the time of this research authors were range scientist and research associate USDA Agricultural Research Service, U.S. Sheep Experiment Station, Dubois, ID 83423; graduate research assistant and professor Department of Range Science, Utah State University, Logan, 84322-5230,

\begin{abstract}
The objective of these studies was to compare preference for leafy spurge (Euphorbia esula L.) by sheep and goats. Study 1 was a choice test that paired leafy spurge with either arrowleaf balsamroot (Balsamorhiza sagittata (Pursh)Nutt.) or crested wheatgrass (Agropyron cristatum (L.)Gaertn.) for a 30 minute feeding period. Study 2 consisted of 3 grazing trials on spurgeinfested pastures. Differences between sheep and goat grazing were measured using capacitance meter estimates of standing crop and ocular estimates of composition; counts of grazed and ungrazed leafy spurge stems; and bite counts to estimate botanical composition of diets. The paired choice study showed that selection for leafy spurge was affected by the interaction $(P<\mathbf{0 . 0 0 0 1 )}$ of animal species and the choice alternative. Goats preferred leafy spurge ( $80 \%$ of consumption) compared to arrowleaf balsamroot, but demonstrated a relative avoidance (33\% of consumption) of leafy spurge when paired with crested wheatgrass. Sheep always avoided leafy spurge compared to the alternative forage and consumed an average of only $28 \%$ of their intake from leafy spurge during the $\mathbf{3 0}$ minute test. In the grazing trials goats took $64 \%$ of their bites from leafy spurge compared to $20 \%$ for sheep. This represented a relative preference for spurge by goats compared to a strong relative avoidance by sheep. Sheep avoided areas in the pasture that had high densities of flowering spurge stems while goats were relatively unresponsive to stem densities. Goat grazing reduced the number of flowering stems. Stem numbers were 90 vs. 23 flowering stems m $^{-2}$ $(P=.04)$ in sheep- and goat-grazed pastures, respectively. Goats appear to have a greater potential for biological control of leafy spurge than sheep. This advantage may be particularly important in areas where leafy spurge is relatively unpalatable, which the present study site represented.
\end{abstract}

Key Words: Euphorbia esula, biological control, noxious weed, dietary habits

Noxious weed invasion is a serious threat to native plant communities in the western U.S. Impacts of noxious weed invasion include

Authors wish to express our appreciation to Dave Swanson for technical assistance in data collection. Appreciation is expressed to Sheridan Golden Eagle Ranches for providing land for this study. This research was supported in part by a grant from the Cooperative States Research Service (91-38300-6158).

Manuscript accepted 23 Apr. 1994. loss of biodiversity (Tyser and Key 1988, Rice et al. 1992), increased soil erosion (Lacey et al. 1989), loss of wildlife habitat (Wallace et al. 1992) and loss of carrying capacity for domestic livestock (Hein and Miller 1992). After half a century of research on controlling leafy spurge, it has been largely defiant of man's efforts to find effective control systems that are economically and environmentally acceptable (Lorenz 1990). The use of domestic livestock to control weeds is not new (Helgeson and Thompson 1939); however, we believe that it is a technology that deserves greater attention.

Leafy spurge (Euphorbia esula L.) is an aggressive perennial weed that typifies the impact of noxious weeds on native plant communities. Although leafy spurge establishment normally occurs on disturbed areas (Belcher and Wilson 1989) it has been reported to invade undisturbed natural areas (Winter 1992). Once established, leafy spurge can displace other vegetation and the infested area is doubling every 10 years (Leistritz et al. 1992). This rate of expansion is particularly alarming because it has occurred in spite of substantial control efforts (Leistritz et al. 1992). Leafy spurge currently infests over 600,000 ha of grazing land in Montana, North Dakota, South Dakota, and Wyoming resulting in approximately $\$ 13$ million of foregone income to ranchers (Bangsund and Leistritz 1991, Leistritz et al. 1992). Furthermore, the biophysical impacts of leafy spurge on wildlife associated recreation, soil and water conservation, and intangible benefits result in direct economic impacts of $\$ 3.6$ million in North Dakota alone (Wallace et al. 1992).

Previous research or anecdotal evidence has shown that sheep (Muenscher 1930; Helgeson and Thompson 1939; Helgeson and Longwell 1942; Wood 1945; Bibbey 1952; Johnston and Peake 1960; Bowes and Thomas 1978; Landgraf et al. 1984; Bartz et al. 1985, Walker et al. 1992a) and goats (Fay et al. 1989, Foss and Parman 1989, Stoneberg 1989, Fay 1991, Walker and Kronberg 1992) consume leafy spurge. Although it is commonly accepted that sheep can be used to control leafy spurge, anecdotal evidence indicates that sheep will not graze this plant in some areas (Russell Lorenz, personal communication 1990). The preference for this plant relative to other available herbage species has not been well documented nor has the preference for spurge by sheep been directly compared to goats. The objective of this study was to compare preference for leafy spurge by sheep and goats under confinement feeding and free grazing conditions.

\section{Methods and Materials}

This research consisted of a feeding study, three field trials and an aversion trial conducted during 1990 and 1991 . Field trials were conducted $2 \mathrm{~km}$ east of Spencer, Idaho $\left(112^{\circ} 10^{\prime} \mathrm{W}, 44^{\circ} 21^{\prime} \mathrm{N}\right)$, which is 
located on the upper Snake River Plains of southeastern Idaho. Sheep used in this study were typical of white-face western range sheep and included Polypay, Columbia, Rambouillet and Targee breeds. Goats were Spanish and dairy crossbreds.

\section{Study 1: Paired Choice Test}

Study 1 was a confinement feeding trial to compare intake by sheep and goats ( $n=10$ per species) of leafy spurge paired with either arrowlcaf balsamroot (Balsamorhiza sagittata (Pursh)Nutt.) or crested wheatgrass (Agropyron cristatum (L.)Gaertn.). Animals were mature (greater than 2 years of age) non-lactating females that had not previously consumed leafy spurge, but had grazed ranges where crested wheatgrass and arrowleaf balsamroot were present. Animals were individually penned for a 7-day adaptation period and fed a base diet of alfalfa pellets. Following an overnight fast (2000 - 0700), animals were offered $200 \mathrm{~g}$ each of freshly harvested whole plants of leafy spurge and an alternative forage in adjacent feeders, for $30 \mathrm{~min}$ utes. All plant materials were in the vegetative stage. Tests were conducted on 4 consecutive days. The 4 tests consisted of 2 trials pairing leafy spurge with arrowleaf balsamroot in either the left or right position, followed by 2 trials pairing leafy spurge with crested wheatgrass in either the left or right position. The objective of this study was to determine the effect of species of animal on relative preference for leafy spurge while minimizing confounding factors associated with grazing, such as harvestability.

Leafy spurge consumption was expressed as a percent of total intake. All calculations were made on a dry matter basis although results were similar on a fresh weight basis. Study 1 was analyzed using a mixed model repeated measures analysis of variance with animal species as a between animal factor and alternate forage and position as within animal factors. The experimental units were the individual animals. Residuals from the percentage data in this study, and other studies presented in this paper were normally distributed (Shapiro and Wilk 1965); therefore, data were not transformed before analysis.

\section{Study 2: Grazing Studies}

Three grazing trials were conducted on leafy spurge-infested rangeland with level topography adjacent to an ephemeral stream. Soils on the area are a St. Anthony gravelly sandy loam (loamyskeletal, mixed, frigid Pachic Haploxerolls). Elevation is about 1,850 $\mathrm{m}$ and average annual precipitation is $460 \mathrm{~mm}$. Peak total herbage production on this area is around $1,500 \mathrm{~kg} \mathrm{ha}^{-1}$ with approximately 50,40 , and $10 \%$ of the standing crop produced by leafy spurge, grass, and forbs, respectively. Dominant graminoids on the study site include Sandberg's bluegrass (Poa sandergii Vasey) with lesser amounts of bluebunch wheatgrass [Pseudoroegneria spicata (Prush) Löve] and needle and thread (Stipa comata Trin. \& Rupr.).

Pasture size was based on initial standing crop and estimated intake of the 2 animal species with the objective to remove $75 \%$ of initial standing crop in 10 days. Pasture size averaged 0.09 and 0.08 ha for sheep and goats, respectively and each was stocked with 3 adults and their offspring. In 1990 goat pastures were $85 \%$ as large as sheep pastures. In 1991 goat pastures were $80 \%$ as large as sheep pastures because sheep had utilized vegetation more heavily than goats the previous year. There were 3 replicate pastures for each animal species and replicates were blocked to accommodate a perceived north to south gradient in leafy spurge density. Pastures were fenced for each trial and treatments were allocated to pastures in a stratified random manner for each trial. Pastures were not regrazed in the same year.

The studies were begun on 1 June 1990, 24 June 1991 and 21 August 1991 and lasted 20,9, and 5 days, respectively. The animals used in 1990 were the same animals used in the paired feeding trial a month pervious to the grazing trial and thus were nonlactating. The animals used in 1991 were lactating. In 1991 the same animals were used for both grazing trials and remained on leafy spurge infested pastures between trials. Prior to the first trial each year animals were separated by species and allowed to graze areas adjacent to study pastures for 1 week before the trial began.

Preference for leafy spurge was measured using a variety of plant and animal parameters. A multiple probe capacitance meter was used to non-destructively estimate standing crop biomass (Neal et al. 1976) on permanently marked plots before, in the middle, and a day after each grazing trial. Twenty and 14 plots $(0.3 \times 0.6 \mathrm{~m})$ in 1990 and 1991, respectively were systematically located in each pasture. A minimum of $12 \%$ of the plots were clipped to calibrate the instrument. Coefficients of determination for the calibration equations were 83,95 , and $89 \%$ for June 1990, June 1991, and August 1991 trials, respectively. Percentage leafy spurge, grass, and other forbs in each plot was ocularly estimated and used to calculate standing crop for each forage class. Changes in standing crop during a trial were expressed as utilization and as herbage disappearance per unit liveweight per day.

Density counts were made in each of the permanent plots. Spurge stems were counted and classified as grazed or ungrazed at each sampling period and the percent grazed stems calculated. Modal height that leafy spurge stems were grazed was also measured. During the June 1991 trial, number of stems that were in flower and the modal height of leafy spurge in the plot were recorded.

Diet composition was determined using the bite count technique and an electronic data logger (Sanders et al. 1980, Walker et al. 1992). Animals were penned overnight to ensure that they did not begin grazing before observations started. Observations began 30 minutes before sunrise and continued throughout the morning grazing bout. All animals were observed using a focal animal sampling procedure (Altman 1974). Observations lasted 3 minutes and multiple observations were taken on each animal with the restriction that each animal in a pasture was observed once before an animal was observed a second time. One observer recorded bites in each pasture. Bites were classified as leafy spurge, forb, grass, or shrub. Multiple observations for each animal were averaged and then means for each pasture calculated before further analysis. Preference for different forage classes was calculated as the difference between the percent of an item in the diet and the percent of that item in the herbage composition (Strauss 1979). This is a normally distributed linear index with a range of preference and avoidance from +100 to -100 centered on 0 (for random feeding).

Preliminary analysis indicated that block was not significant and it was not included in the final statistical analysis for all variables. Vegetation data for the grazing studies were analyzed for the main effect (species) and interaction of animal species and trial using a separate analysis for each period (initial, middle, and final) within a trial. Species by period interactions were not significant thus each period was analyzed separately. The 3 replicate pastures were the experimental unit in these studies and individual plot and animal data were averaged for each pasture before statistical analysis.

Bite count data were analyzed only from the June 1991 trial, because this was the only trial with a complete data set. Initial bite count data were not available for the June 1990 trial because of equipment malfunction. Mid-trial bite counts were not available for the August 1991 because utilization reached targeted levels unexpectedly early. The June 1991 bite count data were analyzed for the main effect of species, period and their interaction. Species was a between sample effect and period was a within sample repeated measure.

Density count data from the mid trial period of the June 1991 trial 
Table 1. Sheep and goat consumption of leafy spurge when paired with crested wheatgrass (Agcr) or arrowleaf balsamroot (Basa) during 30 minutes intake trials.

\begin{tabular}{|c|c|c|c|}
\hline Species" & Agcr & $\begin{array}{l}\text { her For } \\
\text { Basa }\end{array}$ & SE \\
\hline & \multicolumn{3}{|c|}{ (leafy spurge as a \% of total intake) } \\
\hline $\begin{array}{l}\text { Sheep } \\
\text { Goat }\end{array}$ & $\begin{array}{l}25 \\
33\end{array}$ & $\begin{array}{l}32 \\
80\end{array}$ & 4 \\
\hline
\end{tabular}

- Probability of treatment effects Species $x$ Other Forage $P<0.0001$; Species $P<0.0001$; Other Forage $P<0.0001$

were analyzed to determine the effect of leafy spurge density on preference for individual plots. A general linear model was used to fit a response surface for percent of stems grazed at the middle of the trial as the dependent variable. Total and flowering stem density (no. $\mathrm{m}^{-2}$ ) and modal height of leafy spurge plants at the beginning of the trial were independent variables. Separate equations were fit for sheep and goats and the equations were tested for coincidence.

\section{Results}

\section{Study 1: Paired Choice Test}

The paired choice study showed that selection for leafy spurge was affected by the interaction $(P<0.0001)$ of animal species and the choice alternative (Table 1). Goats preferred leafy spurge $(80 \%$ of consumption) compared to arrowleaf balsamroot, but demonstrated a relative avoidance ( $33 \%$ of consumption) of leafy spurge when paired with crested wheatgrass. Sheep always avoided leafy spurge compared to the alternative forage and consumed an average of only $28 \%$ of their intake from leafy spurge during the 30 minutes test.

\section{Study 2: Grazing Trials}

Vegetation measurements varied significantly among trials for most parameters, but the Trial by Species interaction was not significant for any of the vegetation parameters (Table 2). Initial total standing crop was 226, 136, and $99 \mathrm{gm}^{-2}(P<0.001)$ and declined to 102,36 , and $56 \mathrm{gm}^{-2}(P<0.001)$ for the June 1990, June 1991, and August 1991 trials, respectively.

There were few differences in the standing crop of leafy spurge or total herbaceous vegetation that could be attributed to grazing by different species of livestock (Table 2). Total and leafy spurge standing crop were greater $(P<0.10)$ in the sheep-grazed pastures before and after grazing. Goats utilized a greater percentage $(P=0.07)$ of leafy spurge compared to sheep ( $66 \mathrm{vs.} 51 \%$, respectively), while final utilization of the total standing crop was similar $(P=0.44)$ between the 2 species. The height leafy spurge stems were grazed was similar $(P=0.56)$ for sheep and goats $(14 \mathrm{~cm})$. Disappearance of leafy spurge standing crop per unit of animal liveweight showed that disappear-

Table 2. Effect of sheep compared to goat grazing on standing crop and utilization of leafy spurge infested pastures.

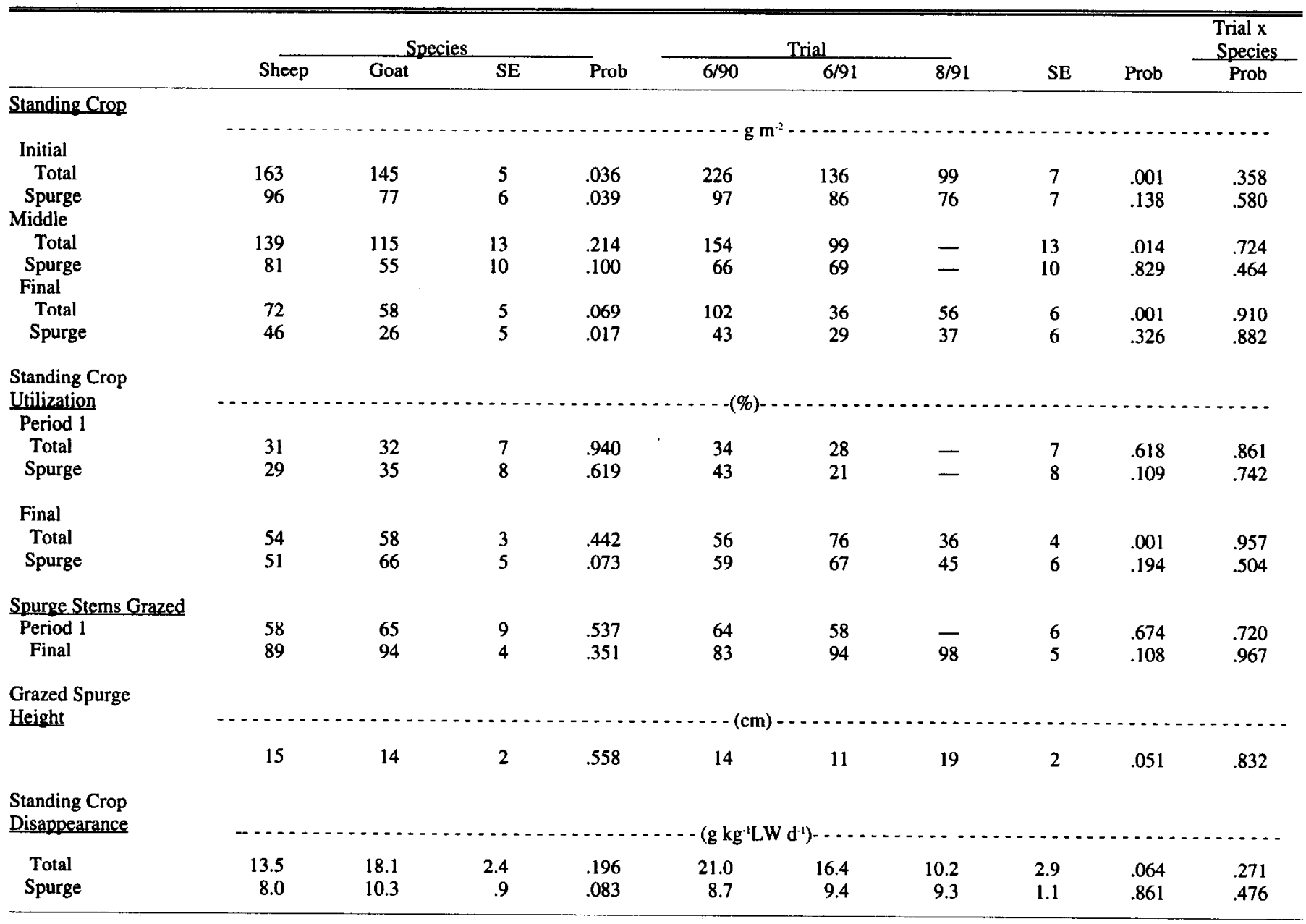


Table 3. Effect of sheep compared to goat grazing on regrowth of leafy spurge 8 weeks after June 1991 trial.

\begin{tabular}{lcccc}
\hline \hline Leafy Spurge & Sheep & Goat & SE & Prob. \\
\hline Initial Stem $\left({\left.\text { no } \mathrm{m}^{2}\right)}\right.$ & 150 & 148 & 16 & .418 \\
Height $(\mathrm{cm})$ & 19 & 14 & 1 & .068 \\
Flowering Stems $\left(\right.$ no m $\left.^{2}\right)$ & 90 & 23 & 15 & .037 \\
\hline
\end{tabular}

ance rates were higher $(P=0.08)$ for goats than sheep, while total vegetation disappearance rate was similar for species. Eight weeks after the June 1991 trial leafy spurge was taller $(P=0.07)$ and produced more flowers $(P=0.04)$ in sheep-compared to goat-grazed pastures (Table 3).

Compared to sheep, goats consumed a greater proportion $(P=0.007)$ of their bites from leafy spurge and less $(P=0.004)$ from grass, while forb consumption was similar ( $P=0.415$, Table 4). Botanical composition of diets was not affected by period within a trial $(P>0.32)$ or the interaction of species and period $(P>0.38)$.

The linear preference index for leafy spurge was affected by species, period and their interaction (Table 4). Goats preferred spurge and avoided grass $(P<0.03)$, while sheep showed opposite preferences. The species by period interaction $(P<0.05)$ was caused by a decline in the absolute value of preference indices for goats compared to an increase in their absolute value for sheep. This indicates that as the vegetation was progressively defoliated, goats were less selective and sheep were more selective. As spurge became less available during the progressive defoliation of the pasture goats switched to the more available grass. In sheep-grazed pastures the opposite occurred. As the pasture was progressively defoliated, grass became less abundant but sheep continued to consume grass at levels similar to when the trial began, resulting in an even greater avoidance of leafy spurge than during the initial phase of the trial.

Response surface analysis showed the linear and quadratic effect for total and flowering stem density were related $(P<0.05)$ to percent of stems grazed for sheep and goats. Furthermore, the coefficients for these terms and the intercept were different $(P<0.01)$ for sheep compared to goats. The coefficient of determination was higher for sheep $\left(R^{2}=0.57\right)$ compared to goats $\left(R^{2}=0.29\right)$. The crossproducts and modal leafy spurge height were not significant $(P>0.05)$ for either species of livestock. Plots of the response surface for sheep and goats showed that the range of response to leafy spurge total and flowering stem densities was greater for sheep compared to goats (Fig. 1). Sheep

Table 4. Diet compositin estimated from bite count observations on sheep and goats grazing leafy spurge infested pastures during June 1991.

\begin{tabular}{|c|c|c|c|c|c|c|c|c|}
\hline & \multicolumn{5}{|c|}{ Period } & \multirow{2}{*}{\multicolumn{3}{|c|}{ Probability }} \\
\hline & \multicolumn{2}{|c|}{ Initial } & \multicolumn{3}{|c|}{ Middle } & & & \\
\hline & Sheep & Goat & Sheep & Goats & SE & Species & Period & $\begin{array}{l}\text { Species } \\
\mathrm{x} \text { Period }\end{array}$ \\
\hline \multicolumn{9}{|l|}{$\begin{array}{l}\text { Percent } \\
\text { of Bites }\end{array}$} \\
\hline Spruge & 21 & 67 & 20 & 62 & 3 & .007 & .436 & .484 \\
\hline Grass & 73 & 30 & 77 & 33 & 4 & .004 & .427 & .978 \\
\hline $\begin{array}{l}\text { Forb } \\
\text { Linear }\end{array}$ & 5 & 2 & 2 & 2 & 2 & .415 & .236 & .385 \\
\hline \multicolumn{9}{|c|}{ Preference $^{1}$} \\
\hline Spurge & -30 & 21 & -56 & 8 & 2 & .032 & .001 & .014 \\
\hline Grass & 34 & -14 & 56 & -9 & 3 & .021 & .011 & .053 \\
\hline Forb & -4 & -7 & -2 & -3 & 2 & .554 & .222 & .743 \\
\hline
\end{tabular}

'Linear Preference $=$ Percent of category in diet-Percent of category in herbage. grazed less on plots with high flowering stem densities and preferred plots with intermediate total stem densities. As indicated by the lower coefficient of determination goats were relatively unresponsive to changes in either total or flowering stem density.

\section{Discussion}

Both the confinement feeding trial and the grazing trials showed goats had a higher preference for leafy spurge than sheep. However, this difference is not straightforward. In the confinement feeding trial (Study 1), goats varied their preference for leafy spurge in response to the alternative forage available while sheep avoided it regardless of the alternative forage. In grazing trials, composition of diets for both sheep and goats remained rather constant over time even though pasture standing crop and composition were changing. In the grazing trials, goats took approximately 3 times more bites from leafy spurge than sheep did. As the trials advanced and the pastures were progressively defoliated, sheep used increasingly more effort to select grass over leafy spurge, as indicated by the relatively greater values for the selectivity index in the middle period compared to the beginning

\section{Sheep}

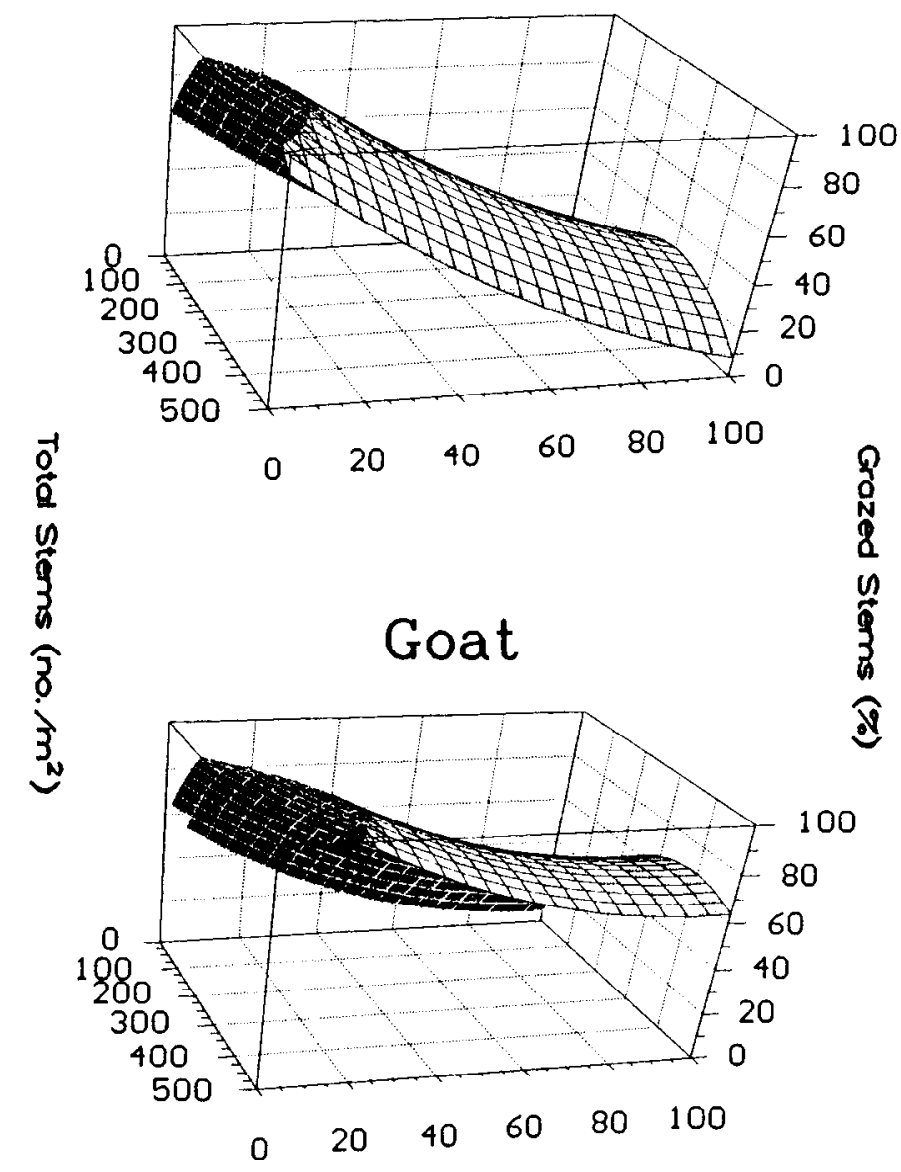

Flowering stems (no. $/ \mathrm{m}^{2}$ )

Fig. 1. Quadratic response surface representing the effect of total and flowering leafy spurge density on percent of stems grazed by sheep $\left(R^{2}=0.57 ; P<0.0001\right)$ and goats $\left(R^{2}=0.29 ; P<0.0117\right)$. 


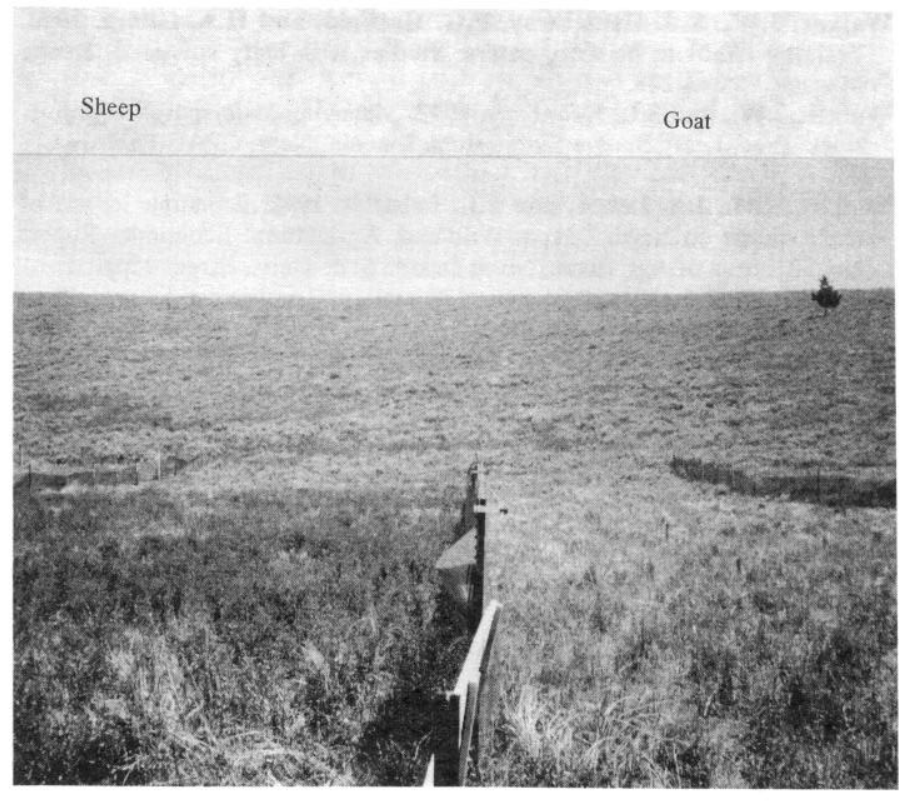

Fig. 2. Fenceline contrast showing difference between sheep (left) and goat (right) grazed pastures midway through June 1990 trial.

period (Table 4). The apparent decrease in selectivity by goats was the result of a relative decline in the proportion of leafy spurge in the herbage, which caused herbage composition to more nearly equal diet composition.

There appear to be 2 reasons for the greater preference for leafy spurge by goats compared to sheep. First, we have shown that leafy spurge causes conditioned food aversions in sheep but not goats (Kronberg et al. 1993). Thus, sheep grazing spurge are probably receiving negative postingestive feedback that limits their consumption while goats are not. Secondly, the regression analysis (Fig. 1) indicated that sheep grazing of spurge was greatly reduced at high stem densities while goats were relatively unresponsive to the different stem densities among plots in a pasture. Sheep consumption of leafy spurge was probably limited in areas of the pasture with high stem densities because the vegetation was structurally unacceptable.

The vegetation measurements did not show as clearly as the bite count data the difference in leafy spurge defoliation between sheepand goat-grazed pastures. A possible reason for equivocal results from the vegetation measurements is a relatively large proportion of leafy spurge in the stem may be an ungrazable residual. If this proportion were equal to $30 \%$ of the ungrazed biomass then utilization of the grazable standing crop would have been 73 and $94 \%$ for sheep and goats, respectively. This is a 21 percentage unit difference compared to the 15 percentage unit difference between species shown in Table 2. The lack of difference in percent of stems grazed was in part caused by counting any evidence of defoliation as grazed. By the end of a trial, goats compared to sheep, grazed 5 percentage units more of the stems but consumed 15 percentage units more of the leafy spurge standing crop. This indicates leafy spurge plants selected by goats were defoliated more intensely than plants selected by sheep. In contrast to the quantitative vegetation measurements that showed relatively minor differences in amount of utilization of leafy spurge, the photograph in Figure 2 suggest a substantial increase in leafy spurge utilization by goats compared to sheep. Measurements of leafy spurge regrowth after the June 1991 trial also showed goat grazing had a greater impact on spurge than sheep grazing.

The results of this study suggest goats are a better biological con- trol agent for leafy spurge than sheep. However, managerial and marketing difficulties associated with goats may reduce their viability as a control animal. Furthermore there are many documented (Helgeson and Thompson 1939, Helgeson and Longwell 1942, Johnston and Peake 1960, Bowes and Thomas 1978) and anecdotal (Lacey et al. 1984) reports of sheep grazing providing an acceptable management strategy for leafy spurge. Thus, it is important to understand under what conditions goats are more appropriate than sheep. Other studies have shown that leafy spurge in this area is less palatable than populations in central North Dakota (Kronberg et al. 1992). This study indicates that goats will provide greater advantage for leafy spurge control on those areas where sheep do not graze it readily.

\section{Literature Cited}

Altman, J. 1974. Observational study of behavior: sampling methods. Behav. 49:227-265.

Bangsund, D.A., and F.L. Leistritz. 1991. Economic impacts of leafy spurge on grazing lands in the Northern Great Plains. Agricultural Economics Report No. 275-S, Dep. of Agr. Econ., North Dakota State Univ., Fargo, N.D. $11 \mathrm{pp}$.

Bartz, S., F. Landgraf, P. Fay, and K. Havstad. 1985. Leafy spurge (Euphorbia esula) as a forage component for ewes and lambs. SID Res. Digest, Winter 1985. p. 39-42.

Belcher, J.W., and S.D. Wilson. 1989. Leafy spurge and the species composition of a mixed-grass prairie. J. Range. Manage. 42:172-175.

Bibbey, R.O. 1952. Beware of leafy spurge. 125. Ontario Dep. Agr. Circ. 125. 5pp.

Bowes, G.G., and A.G. Thomas. 1978. Longevity of spurge seeds in soil following various control programs. J. Range Manage. 31:137-140.

Fay, P.K., V.T. McElligott, and K.M. Havstad. 1989. Containment of freeranging goats using pulsed-radio-wave-activated shock collars. Appl. Anim. Behav. Sci. 23:165-171.

Fay, P.K. 1991. Goats as an alternative to leafy spurge control. In Rochè, B.E., and C.T. Rochè (eds.) Range Weeds Revisited Symposium Proc. Wash. State Coop. Ext. Serv. Pullman, WA. p.59-60.

Foss, E.E., and M.D. Parman. 1989. Leafy spurge (Euphorbia esula) management on the Pothook Ranch, Culbertson, MT. Proc Soc. Range Mange. Abstract no. 124.

Hein, D.G., and S.D. Miller. 1992. Influence of leafy spurge on forage utilization by cattle. J. Range Manage. 45:405-407.

Helgeson, E.A., and E.J. Thompson. 1939. Control of leafy spurge by sheep. North Dakota Agr. Exp. Sta. Bi-monthly Bull. II:5-9.

Helgeson, E.A., and J.H. Longwell. 1942. Control of leafy spurge by sheep. North Dakota Agr. Exp. Sta. Bi-monthly Bull. IV:10-12.

Johnston, A., and R.W. Peake. 1960. Effect of selective grazing by sheep on the control of leafy spurge (Euphorbia esula L.). J. Range Manage. 13:192195.

Kronberg, S.L., J.W. Walker, and R.J. Lorenz. 1992. Differential grazing of leafy spurge by sheep in Idaho and North Dakota. In Abstr. 45 Ann. Meeting Soc. Range Manage.

Kronberg, S.L., J.W. Walker, and C.D. Cheney. 1993. Learning as a proximate causal mechanism of feeding niche separation in sympatric herbivores. In Abstr. 47 Ann. Meeting Soc. Range Manage.

Lacey, C.A., R.W. Kott, and P.L. Fay. 1984. Ranchers control leafy spurge. Rangelands 6:202-204.

Lacey, J.R., C.B. Marlow, and J.R. Lane. 1989. Influence of spotted knapweed (Centaurea maculosa) on surface runoff and sediment yield. Weed Tech. 3:627-631

Landgraf, B.K., P.L. Fay, and K.M. Havstad. 1984. Utilization of leafy spurge (Euphorbia esula) by sheep. Weed Sci. 32:348-352.

Leistritz, F.L., F. Thompson, and J.A. Leitch. 1992. Economic impact of leafy spurge (Euphorbia esula) in North Dakota. Weed Sci. 40:275-280.

Lorenz, R.J. 1990. Leafy spurge control: the decade ahead. North Dakota Agr. Exp. Sta. Leafy Spurge News. 11(3).

Muenscher, W.C. 1930. Leafy spurge and related weeds. New York State Col. of Agr. Ext. Bull. 192. 10pp.

Neal, D.L., P.O. Currie, and M.J. Morris. 1976. Sampling herbaceous native vegetation with an electronic capacitance instrument. J. Range Manage. 29:74-77. 
Rice, P.M., D.J. Bedunah, and C.E. Carlson. 1992. Plant community diversity after herbicide control of spotted knapweed. USDA Forest Service Intermountain Res. Sta. Ogden, UT. Rep. 460. 6p.

Sanders, K.D., B.E. Dahl, and G. Scott. 1980. Bite-count vs fecal analysis for range animal diets. J. Range Manage. 33:146-149.

Shapiro, S.S., and M.B. Wilk. 1965. An analysis of variance test for normality (complete samples). Biometrika 52:591-611.

Stoneberg, S. 1989. Goats make "cents" out of the scourge of leafy spurge. Rangelands 11:264-265.

Strauss, R.E. 1979. Reliability estimates for Ivlev's electivity index, the forage ratio, and a proposed linear index of food selection. Trans. Amer.. Fish Soc. 108:344-352.

Tyser, R.W., and C.W. Key. 1988. Spotted knapweed in natural area fescue grasslands: an ecological assessment. Northwest Science. 62:151-160.
Walker, J.W., K.J. Hemenway, P.G. Hatfield, and H.A. Glimp. 1992. Training lambs to be weed eaters: Studies with leafy spurge. J. Range Manage. 45:245-248.

Walker, J.W., and S.L. Kronberg. 1992. Managing leafy spurge with livestock. Proc. Leafy Spurge Symposium. Lincoln, Nebr. GPAC Publ. 144:423.

Wallace N.M., J.A. Leitch, and F.L. Leistritz. 1992. Economic impact of leafy spurge on North Dakota Wildland. Agricultural Economics Report No. 281. Dep. of Agr. Econ., North Dakota State Univ., Fargo. 25pp.

Winter, B. 1992. Leafy spurge control in a tallgrass prairie natural area. Proc. Leafy Spurge Symposium. Lincoln, NE. GPAC Publ. 144:2-23.

Wood, H.E. 1945. Leafy spurge control. Manitoba Dep. Agr. Pub. No. 200. Winnipeg, Manitoba. 9pp. 